\title{
Nanoparticles for Bioapplications: Study of the Cytotoxicity of Water Dispersible Quantum Dots
}

\author{
Fatemeh Mirnajafizadeh**1, Deborah Ramsey**1, Shelli McAlpine ${ }^{1}$, Fan Wang ${ }^{2,3}$, \\ Peter Reece ${ }^{2}$ and John Arron Stride*1
}

1. School of Chemistry, University of New South Wales, Sydney, NSW 2052, Australia

2. School of Physics, University of New South Wales, Sydney, NSW 2052, Australia

3. School of Mathematical and Physical Sciences, University of Technology Sydney, Ultimo, Sydney, NSW 2007, Australia

Email: j.stride@unsw.edu.au

* Corresponding Author: A/Prof. John Arron Stride
** These authors contributed equally in this work.

Abstract: Semiconductor nanocrystals or quantum dots (QDs), have unique optical and physical properties that make them potential imaging tools in biological and medical applications. However, concerns such as the aqueous dispersivity, toxicity to cells and stability in biological environments may limit the use of QDs in bioapplications. Here, we report an investigation into the cytotoxicity of aqueously dispersed $\operatorname{CdSe}(\mathrm{S})$ and $\mathrm{CdSe}(\mathrm{S}) / \mathrm{ZnO}$ core/shell QDs in the presence of human colorectal carcinoma cells (HCT-116) and a human skin fibroblast cell line (WS-1). The cytotoxicity of the precursor solutions used in the synthesis of the $\mathrm{CdSe}(\mathrm{S})$ QDs was also determined in the presence of HCT-116 cells and compared to that of the heat-shock protein (Hsp90) inhibitor, 17-AAG. CdSe(S) QDs were found to have a low toxicity at concentrations up to $100 \mu \mathrm{g} / \mathrm{ml}$, with a decreased cell viability at higher concentrations, indicating a highly dose-dependent response. Meanwhile, $\mathrm{CdSe}(\mathrm{S}) / \mathrm{ZnO}$ core/shell QDs exhibited lower toxicity than uncoated QDs at higher concentrations. Confocal microscopy images of HCT-116 cells after incubation with $\mathrm{CdSe}(\mathrm{S})$ and $\mathrm{CdSe}(\mathrm{S}) / \mathrm{ZnO}$ QDs showed that the cells were stable in aqueous concentrations of $100 \mu \mathrm{g}$ of QDs per ml, with no sign of cell necrosis, confirming the cytotoxicity data.

Key words: HCT-116, WS1, water dispersive QDs, aqueous synthesis, cytotoxicity of QDs. 


\section{Introduction}

Semiconductor nanocrystals or quantum dots (QDs) have received a great deal of attention over the last decade due to their unique optical and physical properties. This has led to them being classified as a powerful new class of bio-imaging tools [1-8]. Despite the desirability of using QDs as intense fluorescent nanoscale markers in biological applications, cytotoxicity is a serious constraint that limits potential uses [9-11]. QDs can be considered as being potentially toxic due to both their nanoscale size and the presence of heavy metals $[10,11]$. Nanoscale particles can have a greater toxicity than bulk counterparts, with the small size enabling greater penetration into cells than corresponding bulk chemical materials [12]. In addition, the generation of free radicals such as reactive oxygenated species (ROS) upon cell exposure to nanomaterials, is a significant cause of nanoparticle cytotoxicity [12-15]. Interactions of QDs with cell mitochondria and nuclei can result in the disruption of cell function, inhibition of cell proliferation and decreased cell viability due to ROS production, ultimately resulting in cell death, mutation, or induced immunotoxicity [13, 16-18]. The longterm toxicity of QDs has also been attributed to bioaccumulation in organs, leading to organ damage and chronic illnesses [19]. The high ratio of reactive surface area relative to the bulk generally increases the chemical activity of nanoparticles, which can result in an accumulation of nanoparticles in tissues and associated organ toxicity [20], particularly those having high blood flow such as spleen, kidneys, liver and lungs, along with the blood circulation system itself [21]. QDs have therefore largely been classified as poisonous to both human and animal cells and as such, cytotoxicity assays of QDs are an essential requirement before applying QDs to cellular environments.

There are various methods to determine the toxicity of QDs in both in-vivo and in-vitro studies. In-vivo studies may involve introducing QDs to microorganisms [22] or the use of animal models [23-27], whereas in-vitro toxicity features the treatment of various cell types 
with QDs in order to investigate the cytotoxicity of nanocrystals in mammalian cell lines [2837]. A common feature in all reports of cadmium-based QDs, including CdTe, CdSe and $\mathrm{CdS}$, is that $\mathrm{Cd}$ is a primary source of toxicity. Accordingly, core/shell QDs such as $\mathrm{CdTe} / \mathrm{CdS}, \mathrm{CdTe} / \mathrm{CdS} / \mathrm{ZnS}$ and $\mathrm{CdSe} / \mathrm{ZnS}$ have been shown to exhibit less toxicity than core QDs alone [11, 31]. However, the cytotoxicity of QDs depends on a number of parameters including the surface modifications of the QDs, cell type, cellular morphology, cell growth and the interaction of QDs with cell membranes [36, 30].

There are extensive reports detailing cytotoxicity assays of QDs synthesized in organic media [25, 29-39], but few papers have reported in detail the cytotoxicity of QDs directly obtained from aqueous solution [11, 40-43]. Bhatia and co-workers investigated the in-vitro cytotoxicity of organically synthesized CdSe QDs on liver cells and showed that the release of free cadmium ions from the QDs resulted in cell death [30]. Meanwhile, Zhu et al. studied both the in-vivo and in-vitro cytotoxicity of aqueous CdSe and CdSe/CdS QDs and reported that the toxicity of QDs depends on both target cells and physicochemical properties of the QDs [42]. Plank et al. investigated the cytotoxicity of CdSe and CdSe/ZnS QDs obtained in organic solvents, demonstrating that QD cytotoxicity is related to both particle size and the surface covering of functional groups such as amines and carboxylic acids used to disperse them in water [32]. Fan et al. investigated the cytotoxicity of a wide range of QDs (CdTe, $\mathrm{CdTe} / \mathrm{CdS}$ and $\mathrm{CdTe} / \mathrm{CdS} / \mathrm{ZnS}$ ) synthesized in aqueous reactions, concluding that free cadmium ions are a major source of toxicity in CdTe-based QDs [11], also reporting that $\mathrm{CdTe} / \mathrm{CdS} / \mathrm{ZnS}$ QDs were slightly less toxic than CdTe in their experiments [11]. The present work reports on the cytotoxicity of $\mathrm{CdSe}(\mathrm{S})$ and $\mathrm{CdSe}(\mathrm{S}) / \mathrm{ZnO}$ QDs, synthesized in wholly aqueous reactions, to human colorectal carcinoma cells (HCT-116) and human skin fibroblast cells (WS1). The water dispersible QDs were synthesized in a modified literature method [44] and the cytotoxicity of both the QDs and the precursor solutions were determined after 
incubation of HCT-116 cells with the QDs over a wide range of concentrations (25 to 500 $\mu \mathrm{g} / \mathrm{ml})$. Cytotoxicity of $\mathrm{CdSe}(\mathrm{S})$ QDs was benchmarked against the heat-shock protein (Hsp90) inhibitor, 17-AAG, and confocal images of HCT-116 cells after treatment with QDs were recorded. Cytotoxicity of QDs to WS1 cells was also studied to explore the action of QDs toward normal, resilient cell types.

\section{Experimental methods}

\subsection{Materials}

3-mercaptopropionic acid (MPA) was obtained from Fluka. $\mathrm{CdCl}_{2} \cdot 2.5 \mathrm{H}_{2} \mathrm{O}$, $\mathrm{Zn}\left(\mathrm{CH}_{3} \mathrm{COO}\right)_{2} .2 \mathrm{H}_{2} \mathrm{O}, \mathrm{NaBH}_{4}$, Se (powder), $\mathrm{NaOH}$, bisbenzimide (Hoechst 33342), 4',6diamidino-2-phenylindole (DAPI) and 17-allyamino-17-demethoxy-geldanamycine (Hsp90 inhibitor 17-AAG) were all obtained from Sigma-Aldrich. Human colorectal carcinoma cells (HCT-116) and human skin fibroblast cells (WS1) were obtained from ATCC (Manassas, Virginia, USA). Dulbecco's modified eagle medium (DMEM), fetal bovine serum (FBS), penicillin, streptomycin, L-glutamine and nonessential amino acids were received from Invitrogen. All reagents were used as supplied, without additional purification. Ultra-pure water was used in all syntheses.

2.2.1 Synthesis of QDs: Water dispersible $\mathrm{CdSe}(\mathrm{S})$ and $\mathrm{CdSe}(\mathrm{S}) / \mathrm{ZnO}$ QDs were synthesized and characterized using optimized experimental parameters in a modified literature method [44], as detailed in Supplementary Data S1.

2.2.2. Characterization of QDs: UV-vis absorption spectra were measured with a Varian Cary UV spectrometer. Photoluminescence spectra were measured on a Carry Eclipse fluorometer using an excitation wavelength of $350 \mathrm{~nm}$. X-ray powder diffraction patterns (PXRD) were recorded on an X'pert PRO Multi-purpose X-ray diffraction system (MPD system) with a $\mathrm{Cu} \mathrm{K} \alpha$ source $(\lambda=0.154056 \mathrm{~nm})$. X-ray photoelectron spectroscopy (XPS) 
was performed using an Escalab 250Xi spectrometer and a monochromated Al Ka X-ray source $(h v=1486.6 \mathrm{eV})$ operated at $10 \mathrm{kV}$ and $10 \mathrm{~mA}$. High resolution transmission electron micrographs (HRTEM) were obtained using a Philips CM200 instrument.

2.2.3 Preparation of aqueous solutions of QDs: A total of twenty different solutions of $\mathrm{CdSe}(\mathrm{S})$ and $\mathrm{CdSe}(\mathrm{S}) / \mathrm{ZnO}$ QDs, Cd-MPA (Sample 1, Supplementary Data S1) and Cd-SeMPA (Sample 2, Supplementary Data S1) were prepared by diluting the aqueous solutions with ultra-pure water to achieve concentrations of 25, 50, 100, 250, $500(\mu \mathrm{g} / \mathrm{ml})$. Each sample was used in cytotoxicity assays without further purification. In order to remove excess cadmium ions and capping agent from the aqueous solution, a Slide-A-Lyzer dialysis cassette was used in the QD stock solution and the cytotoxicity of dialyzed $\operatorname{CdSe}(\mathrm{S})$ QDs in the presence of HCT-116 cell line was investigated in five samples at concentrations of 25, 50, $100,250,500 \mu \mathrm{g} / \mathrm{ml}$.

2.2.4 Cytotoxicity assays: Cell cultures of human HCT-116 and WS-1 cell lines were obtained according to the standard protocol [45], as detailed in Supplementary Data S2. The cells were then separately seeded in two 96-well plates (3000 cells/well) and allowed to adhere to the dish for 24 hours in a humidified incubator. As a control, both the cell media alone $(3000$ cell/well) and cell media in the presence of Hsp90 inhibitor 17-AAG (100 nM = $0.06 \mu \mathrm{g} / \mathrm{ml}$ ) were also seeded. Finally, $10 \mu \mathrm{l}$ of each aqueous solution was added to the plates. The plates were incubated in the presence of the QDs for 72 hours at $37^{\circ} \mathrm{C}$ with $5 \%$ $\mathrm{CO}_{2}$, after which the samples were analysed to determine the cell proliferation using a Cell Counting Kit-8 assay.

2.2.5 Confocal microscopy studies: first two samples of either fixed or live HCT-116 cellsQDs were prepared (Supplementary Data S3). Images of the cells in the presence of QDs were recorded under Leica TCS SP5 CW STED and Zias LSM 780 confocal microscopes, respectively. The live cells were stained by adding a Hoechst solution $(5 \mu \mathrm{g} / \mathrm{ml}) 10$ minutes 
before recording images, whilst the fixed cells were stained using DAPI. In addition, the emission profiles of QDs in both cell media and aqueous solution were recorded using a Zias LSM 780 confocal microscope.

\section{Results and discussion}

3.1 Synthesis of QDs: the method of synthesising QDs can play an important role in the overall toxicity, with literature reports indicating that QDs synthesized in organic solvents tend to be more toxic than those synthesized by aqueous pathways [46-48]. However, the toxicity of Cd-based QDs has largely been attributed to the free Cd ions existing in equilibrium with the QDs in solution [11, 30, 49]. Coating the QD cores with appropriate shell materials may prevent the core from oxidation, thereby reducing the number of free $\mathrm{Cd}$ ions released $[42,50-54]$. In this work, an aqueous hydrothermal method reported by Aldeek and co-workers [44] was used to synthesise $\mathrm{CdSe}(\mathrm{S})$ and $\mathrm{CdSe}(\mathrm{S}) / \mathrm{ZnO}$ QDs using optimized experimental parameters, leading to the formation of highly crystalline QDs.

PXRD patterns of the synthesized QDs showed that both $\mathrm{CdSe}(\mathrm{S})$ and $\mathrm{CdSe}(\mathrm{S}) / \mathrm{ZnO}$ QD cores had the cubic zinc blende structure (Figure 1), according to the standard CdSe cubic pattern [55]. The diffraction peaks of the QDs were found to be consistent with standard patterns of the cubic phases of CdSe [55] and CdS [56] and are characteristic of alloyed CdSe-CdS, Table S1, Supplementary data. As $\mathrm{ZnO}$ is amorphous, there was no peak observed in PXRD that can be attributed to $\mathrm{ZnO}$. Meanwhile, the cubic structure of $\mathrm{CdSe}(\mathrm{S})$ QDs remained intact after coating with an amorphous $\mathrm{ZnO}$ shell, in accord with a previous report [44]. The size of the core was estimated using the Scherrer equation as $3.6 \pm 0.1$ and 3.0 $\pm 0.1 \mathrm{~nm}$ in $\mathrm{CdSe}(\mathrm{S})$ QDs and $\mathrm{CdSe}(\mathrm{S}) / \mathrm{ZnO}$ QDs, respectively. This indicates a potential decrease in the size of the QD core during the heating process in the formation of the zinc oxide shell. The decreased particle size of the $\mathrm{CdSe}(\mathrm{S})$ QD core after heating using reflux is 
in accord with our previous studies on CdSe nanoparticles [57]. However, the total size of $\mathrm{CdSe}(\mathrm{S}) / \mathrm{ZnO}$ QDs cannot be estimated by using the Scherrer equation because the $\mathrm{ZnO}$ shell is amorphous.

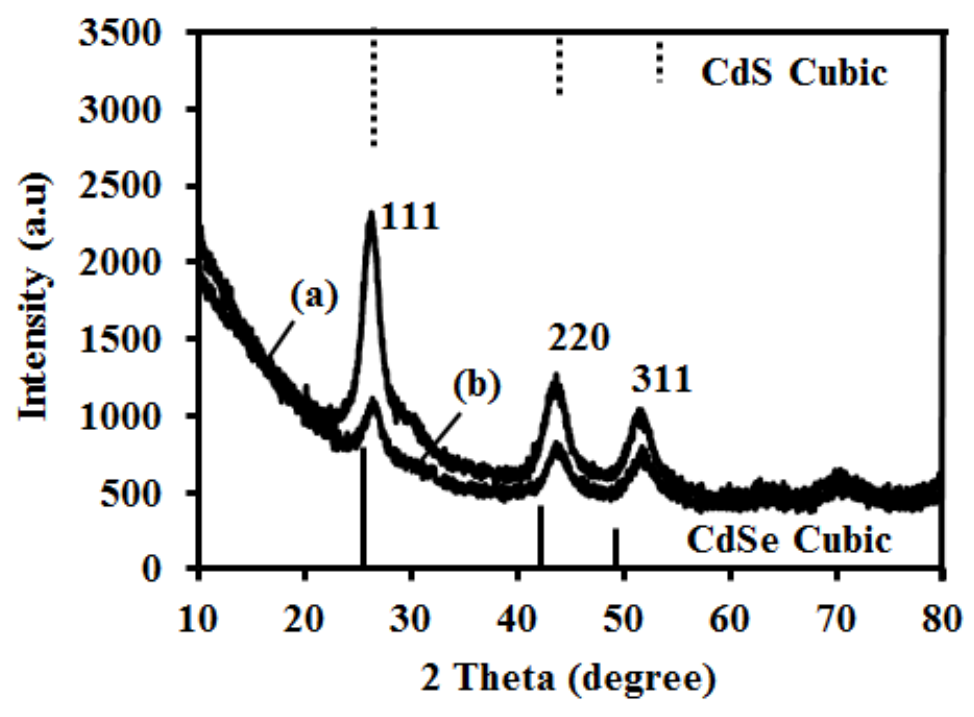

Figure 1. PXRD of as- synthesized QDs: (a) CdSe QDs \& (b) CdSe(S)/ZnO QDs.

HRTEM images of the crystalline NPs showed evidence of atomic planes with a d-spacing

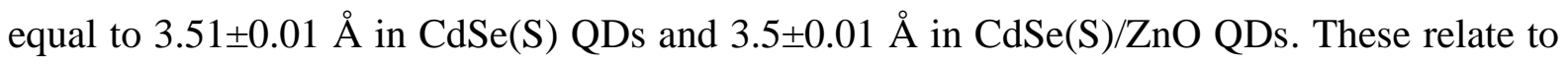
the (111) planes in cubic CdSe, in accord with the PXRD data (Figure 2), which relate to the (111) planes in cubic CdSe, in accord with the PXRD data (Figure 2). Similar to previous reports [44, 54], HRTEM did not show existence of the shell due to the small size of nanoparticles and aggregation. 


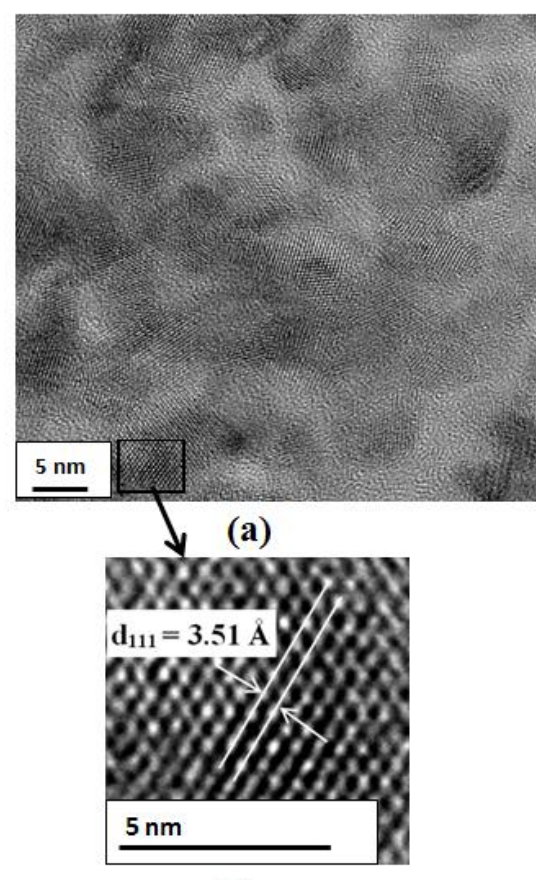

(b)

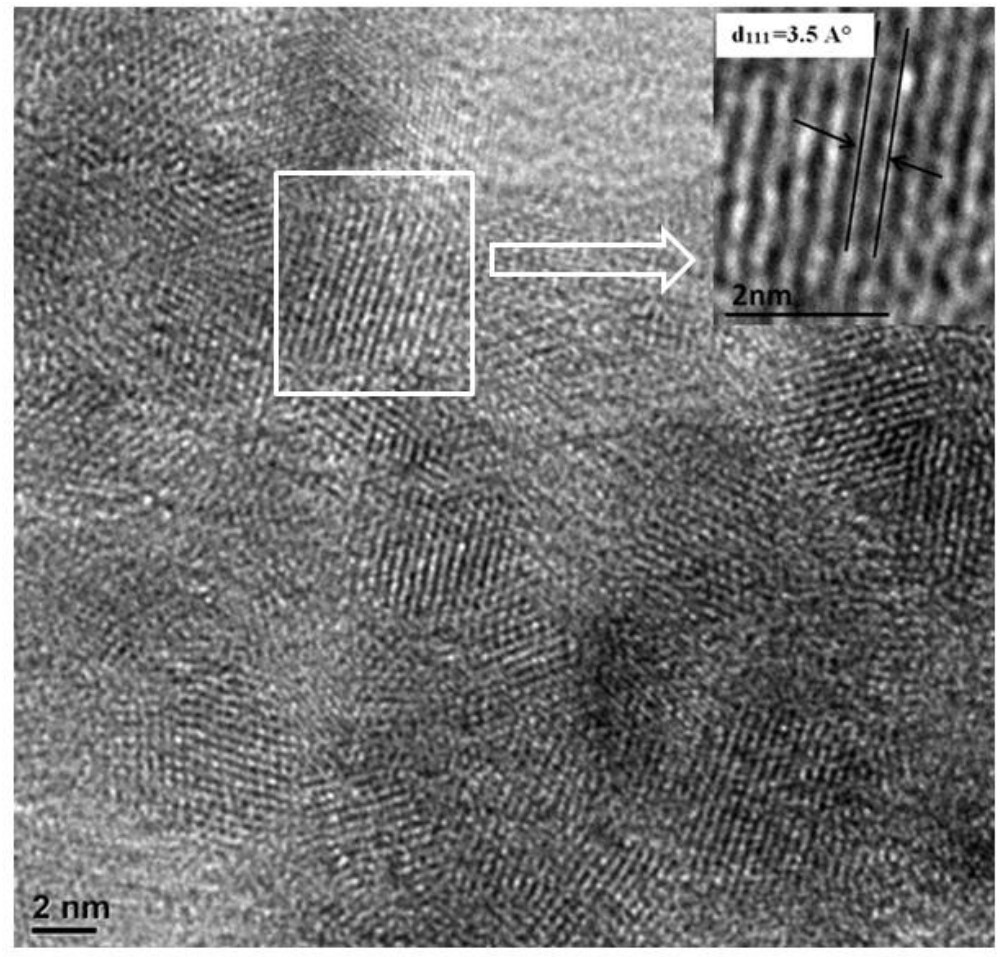

(c)

Figure2: HRTEM images of QDs: (a), (b) CdSe QDs and (c) CdSe(S)/ZnO QDs.

The obtained QDs were found to be highly luminescent, with narrow emission peaks at 560 and $550 \mathrm{~nm}$ for $\mathrm{CdSe}(\mathrm{S})$ and $\mathrm{CdSe}(\mathrm{S}) / \mathrm{ZnO}$ QDs, along with broad excitation bands starting at $530 \mathrm{~nm}$ for $\mathrm{CdSe}(\mathrm{S})$ and $520 \mathrm{~nm}$ for $\mathrm{CdSe}(\mathrm{S}) / \mathrm{ZnO}$ QDs, respectively (Figure 3). The optical properties of the QDs are related wholly to the $\mathrm{CdSe}(\mathrm{S}) \mathrm{QD}$ cores, with the $\mathrm{ZnO}$ present as an amorphous shell, exhibiting no optical properties in this region. 


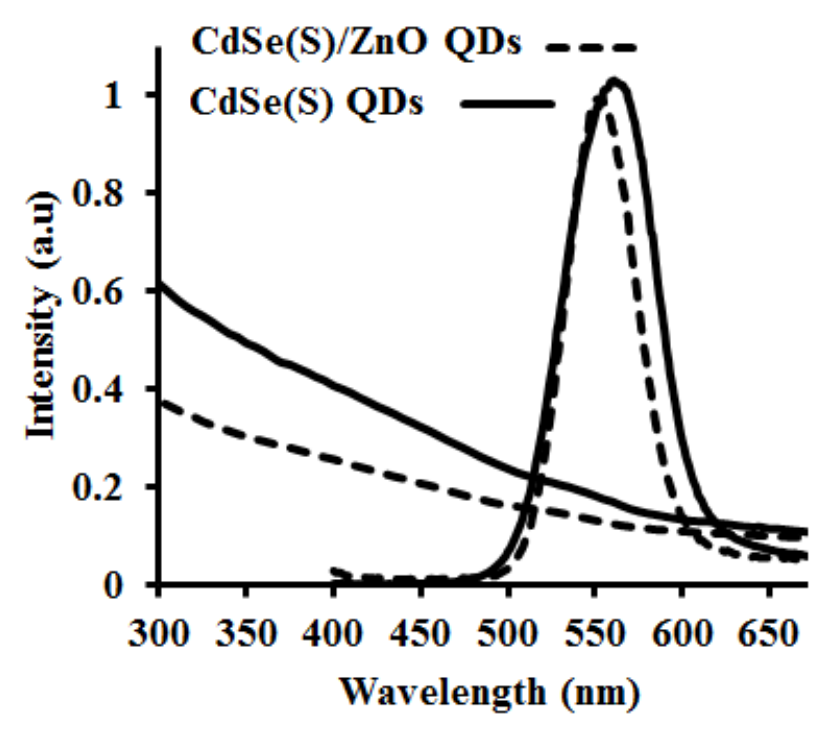

Figure 3. Optical spectra of $\mathrm{CdSe}(\mathrm{S})$ and $\mathrm{CdSe}(\mathrm{S}) / \mathrm{ZnO}$ QDs.

The emission wavelength of the $\mathrm{CdSe}(\mathrm{S}) \mathrm{QDs}(\lambda=560 \mathrm{~nm})($ particle size $=3.6 \pm 0.1 \mathrm{~nm})$ was found to be slightly different to that of CdSe QDs $(\lambda=515 \mathrm{~nm})($ particle size $=2.5 \pm 0.5 \mathrm{~nm})$ reported previously [44], consistent with both the larger particle size and modified Cd:MPA molar ratio used. Moreover, the emission wavelengths of $\mathrm{CdSe}(\mathrm{S}) / \mathrm{ZnO}$ QDs $(\lambda=550 \mathrm{~nm})$ were found to shift to lower wavelengths relative to the cores $\operatorname{CdSe}(\mathrm{S}) \mathrm{QDs}(\lambda=560 \mathrm{~nm})$, in agreement with the estimated particle size $(3.0 \pm 0.1 \mathrm{~nm})$ but in contrast to a previous report [44]. This is primarily due to the sensitivity of QDs on changes in environmental or experimental parameters. For example, Aldeek and co-workers [44] reported that the emission wavelengths of $\mathrm{CdSe}(\mathrm{S}) / \mathrm{ZnO}$ QDs shifted to lower wavelengths compared to uncoated $\mathrm{CdSe}(\mathrm{S})$ QDs after 4 minutes of UV exposure [44], indicating that even small changes in temperature or illumination can lead to shifts in emission and excitation wavelengths of the QDs.

The XPS spectra of both $\mathrm{CdSe}(\mathrm{S})$ and $\mathrm{CdSe}(\mathrm{S}) / \mathrm{ZnO}$ QDs (Figure 4), confirmed the existence of the peaks assigned to selenium, cadmium, sulfur and carbon, indicating that the shell growth does not influence the structure of $\mathrm{CdSe}(\mathrm{S}) \mathrm{QD}$ cores. The presence of sulfur was confirmed with the appearance of peaks characteristic of $S_{2 p}$ at $161.8 \mathrm{eV}$ in XPS data. It is 
also in agreement with previous reports in the literature where MPA releases sulfur at high temperature [58, 59], resulting in sulfur from the 3-mercaptopropionic acid (MPA) participating the growth of $\mathrm{CdSe}(\mathrm{S})$ particles. Indeed, XPS data of $\mathrm{CdSe}(\mathrm{S}) / \mathrm{ZnO}$ QDs confirmed the existence of both $\mathrm{Zn}$ and $\mathrm{O}$ in the core/shell $\mathrm{CdSe}(\mathrm{S}) / \mathrm{ZnO}$ QDs, with the observation of a new peak related to $\mathrm{Zn}_{2 \mathrm{p}}$ at $1022 \mathrm{eV}$ (Figure 4e), indicating the formation of a $\mathrm{ZnO}$ shell around the $\mathrm{CdSe}(\mathrm{S})$ cores; this is consistent with the standard $\mathrm{X}$-ray photo electron spectrum of zinc oxide [60] and in accord with previous work [44].

XPS analysis was also used as quantitative method to determine elemental composition. The atomic percentages of as-prepared QDs, have been summarized in Table 1. This confirmed that $\mathrm{CdSe}(\mathrm{S})$ QDs were coated with a $\mathrm{ZnO}$ shell. The $\mathrm{CdSe}(\mathrm{S})$ QDs contained cadmium (13.7\%), selenium $(0.7 \%)$, sulfur $(13.1 \%)$, oxygen $(29.9 \%)$ and carbon $(42.5 \%)$, with the ratio of atomic percentages $\mathrm{C}: \mathrm{O}: \mathrm{S}=3.2: 2.3: 1$, fully consistent with the molecular composition of the capping agent MPA, $\mathrm{C}_{3} \mathrm{O}_{2} \mathrm{SH}_{6}$. The atomic percentage of $\mathrm{Cd}$ was found to be approximately equal to the sum of the atomic percentages of the Se and S contributions, indicating that at the surface of the CdSe QDs, the MPA coordinates by substitution of $\mathrm{S}$ at the Se sites. The low intensity of the Se peak suggests a low atomic percentage of Se relative to that of S (1:18.2) and is due to the dominance of surface atoms in the XPS data, essentially MPA and the outer surface of the $\mathrm{CdSe}(\mathrm{S})$ QDs. Besides, according to quantitative analysis data (Table 1), the most abundant element in the $\mathrm{CdSe}(\mathrm{S}) / \mathrm{ZnO}$ QD spectrum was $\mathrm{O}(37.7$ atomic \%). Each MPA molecule accounts for two $\mathrm{O}$ and one $\mathrm{S}$ atom; the atomic $\%$ of $\mathrm{S}$ was found to be $12.3 \%$ and so MPA accounts for $24.6 \%$ of the $\mathrm{O}$ contribution, leaving $13.1 \%$, which closely matches the $12.0 \%$ contribution of $\mathrm{Zn}$. The $\mathrm{Cd}$ :(Se+S) ratio of 1:0.8 and $\mathrm{Cd}: \mathrm{Zn}$ of 1:0.7 are fully consistent with a $\mathrm{ZnO}$ shell around the $\mathrm{CdSe}(\mathrm{S})$ core. In addition, the peaks of $\mathrm{Cd}$ and $\mathrm{Se}$ shift with the incorporation of $\mathrm{ZnO}$, highlighting the modified bonding environments at the interfacial atoms. 


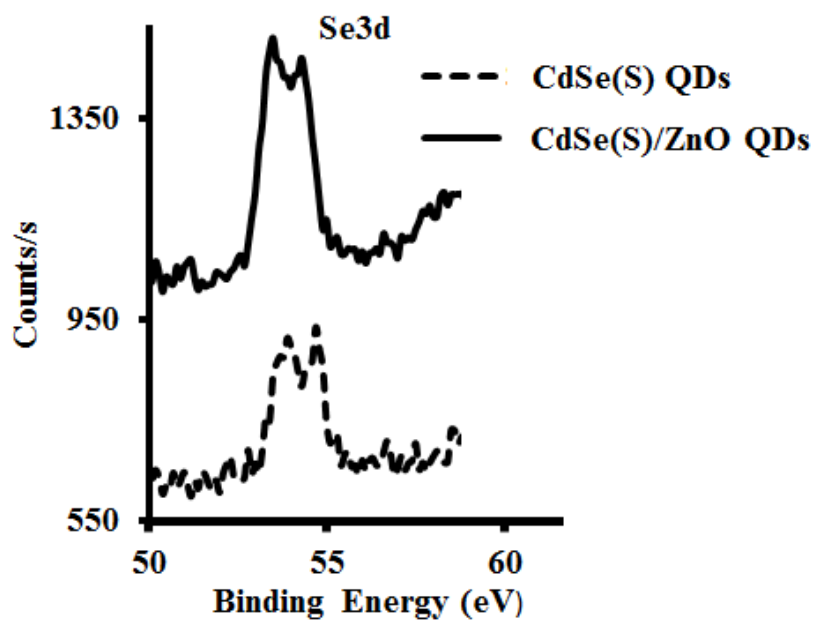

(a)

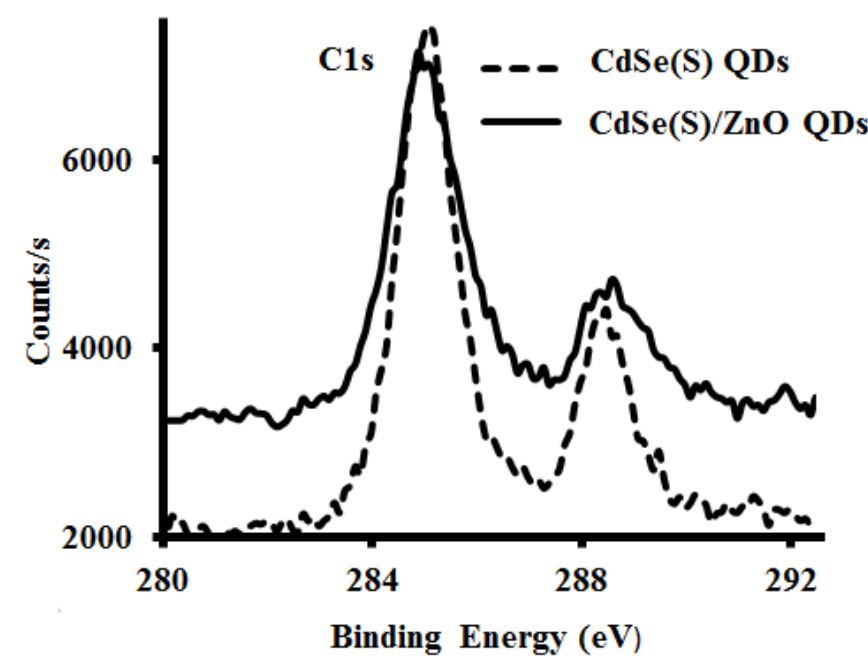

(c)

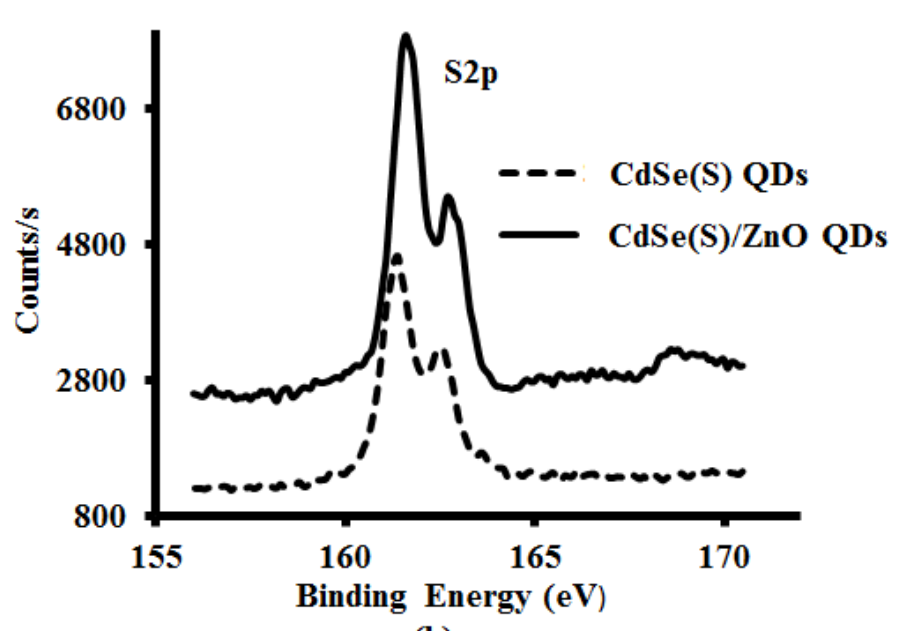

(b)

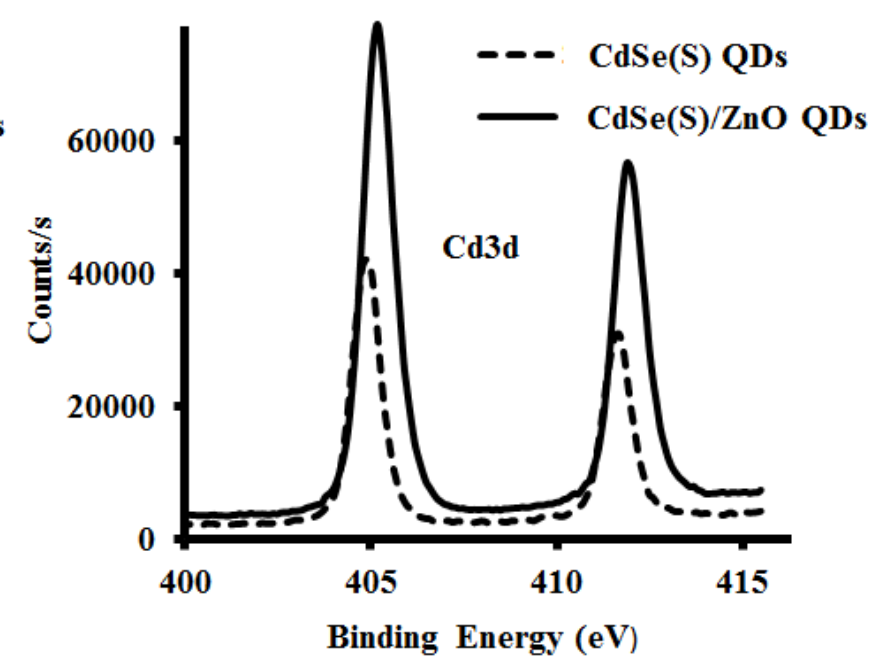

(d)

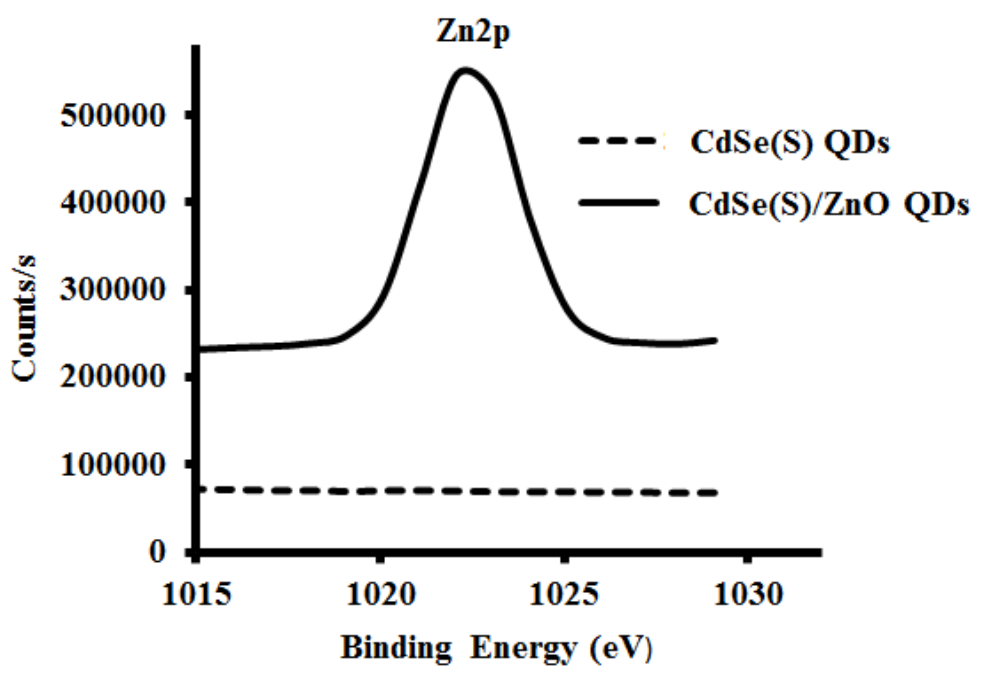

(e)

Figure 4. XPS spectra of $\mathrm{CdSe}(\mathrm{S})$ and $\mathrm{CdSe}(\mathrm{S}) / \mathrm{ZnO}$ QDs. Binding energy of (a) Se $\mathrm{Se}_{3 d}$,

(b) $S_{2 p}$, (c) $C_{1 s}$, (d) $\mathrm{Cd}_{3 d}$ and (e) $\mathrm{Zn}_{2 p}$. 
Table 1. Elemental analysis of QDs.

\begin{tabular}{|c|c|c|c|c|c|c|}
\hline QDs-type & Carbon & Oxygen & Selenium & Cadmium & Sulfur & Zinc \\
\hline CdSe(S) & 42.5 & 29.9 & 0.7 & 13.7 & 13.1 & $\mathbf{0}$ \\
\hline $\mathrm{CdSe}(\mathrm{S}) / \mathrm{ZnO}$ & 20.5 & 37.7 & 0.6 & 16.8 & 12.3 & 12 \\
\hline
\end{tabular}

3.2 Cytotoxicity assays: The response of HCT-116 and WS1 cell lines upon exposure to the QDs was studied in order to investigate toxicity. Cancer cells such as HCT-116 cells have an irregular DNA pattern, making them more sensitive than healthy cells to free heavy metals, including cadmium. In contrast, normal skin cells (WS1) are known to be some of the most resistant cell types to free metal ions. In addition, $50 \%$ of cancer cells, including HCT-116, depend upon a heat-shock protein (such as Hsp90) to survive [61]. The viability of these cancer cells decreases in the presence of Hsp90 inhibitor 17-AAG, which is a common antitumour compound $[62,63]$. The viability of HCT-116 cells was therefore investigated both in the presence of 17-AAG and after treatment of the cells with QDs.

3.2.1 Cytotoxicity of $\mathrm{CdSe}(\mathrm{S})$ QDs toward HCT-116 cells: The lethal concentration corresponding to the death of $50 \%$ of cells $\left(\mathrm{LC}_{50}\right)$ was determined as $105 \mu \mathrm{g} / \mathrm{ml}$ for the HCT116 cell line upon exposure to $\mathrm{CdSe}(\mathrm{S})$ QDs. $\mathrm{CdSe}(\mathrm{S})$ QDs were found to have a low toxicity at the highest dilutions studied $(25$, and $50 \mu \mathrm{g} / \mathrm{ml})$, with $100.0 \pm 0.2 \%, 91.5 \pm 2.6 \%$ cell viability respectively, but have a cell mortality rate of $\geq 50 \%$ at concentrations of $\sim 100 \mu \mathrm{g} / \mathrm{ml}$ and beyond, with a dose-dependent cytotoxicity (Figure 5). 


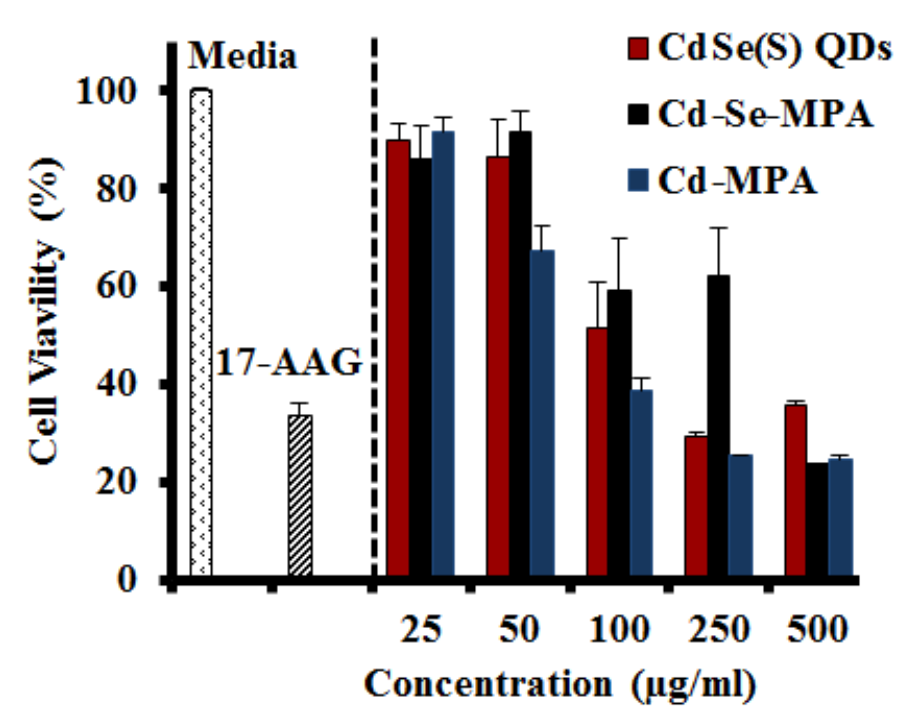

Figure 5. The results of cytotoxicity assays of $\mathrm{CdSe}(\mathrm{S}) \mathrm{QDs}, \mathrm{Cd}-\mathrm{MPA}$ and Cd-Se-MPA precursors toward HCT-116 cell line. Error bars indicate standard error of the mean and the concentration of $17-\mathrm{AAG}$ was $0.06 \mu \mathrm{g} / \mathrm{ml}$

3.2.2 Relative toxicity of $\mathrm{CdSe}(\mathrm{S})$ QDs in comparison to 17-AAG: Hsp90 inhibitor 17AAG is an anti-tumour drug that inhibits the activity of Hsp90, a protein necessary for the growth of the cells $[62,63]$. The cytotoxicity results showed that $\mathrm{CdSe}(\mathrm{S})$ QDs inhibit the cell viability by $64.4 \pm 0.5 \%$ at a concentration of $500 \mu \mathrm{g} / \mathrm{ml}$; a similar value to that of 17 AAG $(66.4 \pm 2.7 \%)$ at a concentration of only $0.06 \mu \mathrm{g} / \mathrm{ml}$ (Figure 5). Hence, CdSe(S) QDs are much less cytotoxic than Hsp90 inhibitor 17-AAG, presumably as a result of non-specific cell activity.

3.2.3 Cytotoxicity of precursor solutions: The $\mathrm{CdSe}(\mathrm{S})$ QDs were synthesised by hydrothermal reactions of two precursor solutions containing Cd-MPA and Cd-Se-MPA. The viability of HCT-116 cells was measured to both of the precursor solutions (Figure 5), which were found to have no significant toxicity at concentrations of 25 and $50 \mu \mathrm{g} / \mathrm{ml}$, but to be cytotoxic at a concentration $500 \mu \mathrm{g} / \mathrm{ml}$, similar to that of $\mathrm{CdSe}(\mathrm{S})$ QDs. The Cd-MPA solution was found to be more toxic than the Cd-MPA-Se precursor solution. In addition, cells treated with the Cd-MPA precursor solution had a lower viability $(67.3 \pm 9.8 \%)$ at 50 
$\mu \mathrm{g} / \mathrm{ml}$ than the Cd-Se-MPA precursor $(97.0 \pm 8.3 \%)$, indicating that formation of the Cd-SeMPA complex decreases the toxicity, presumably due to a decreased number of free cadmium ions.

3.2.4 Cytotoxicity of dialyzed $\operatorname{CdSe}(S)$ QDs: A dialysis cassette was used to remove excess capping agent and cadmium ions from solution, however the results showed that the $\mathrm{CdSe}(\mathrm{S})$ QD solutions were in fact more toxic after dialysis than before (Figure 6). This is consistent with a report of CdTe QDs with thiol capping agents, in which a surface cadmium-thiol shell protected the QDs against oxidation, resulting in greater stability of the QDs [64]. In aqueous solution, QDs are in an active equilibrium with excess cations and thiol in solution. During dialysis, excess thiol and cadmium ions are removed from solution, resulting in the destabilisation of the QD surface, thereby leaching more free cadmium ions into solution and so increasing toxicity.

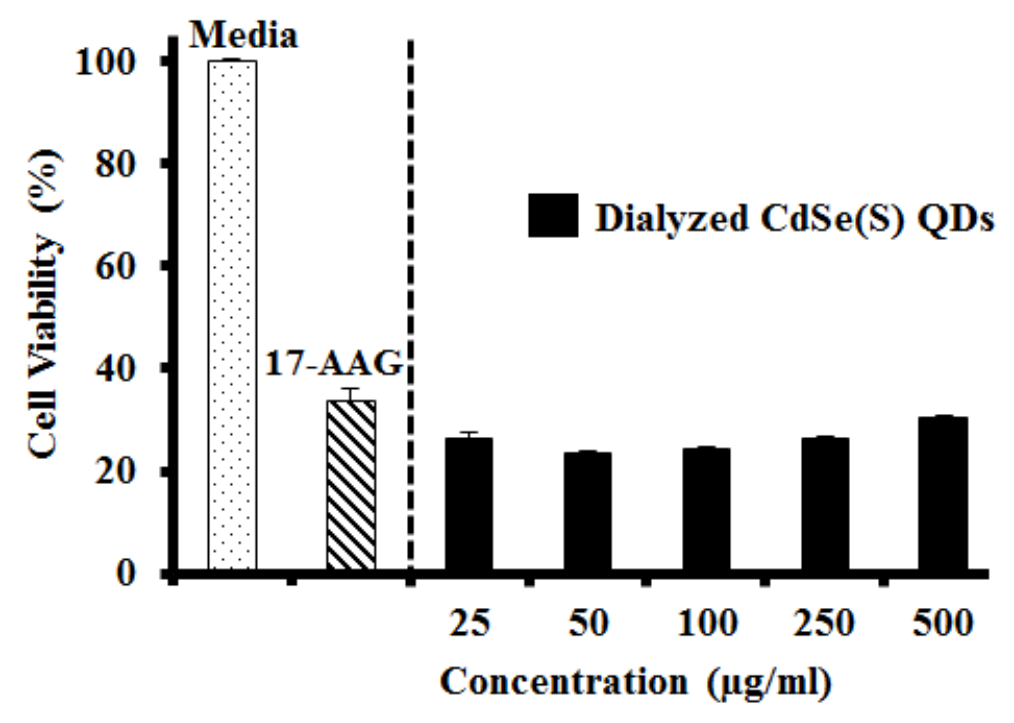

Figure 6. The results of cytotoxicity assays of dialyzed CdSe(S) QDs. Error bars indicate standard error of the mean and the concentration of $17-A A G$ was $0.06 \mu \mathrm{g} / \mathrm{ml}$.

3.2.5 Cytotoxicity of $\mathrm{CdSe}(\mathrm{S}) / \mathrm{ZnO}$ core/shell QDs: Core/shell QD structures, in which a relatively inert shell encapsulates the core, are widely considered to be an efficient method of attenuating the toxicity of QDs, particularly if the core contains metals such as cadmium [42, 
$43,50,52,53,64]$. The toxicity of core/shell $\mathrm{CdSe}(\mathrm{S}) / \mathrm{ZnO}$ QDs towards HCT-116 cancer cells indicated that the core/shell QDs exhibited low toxicity at all concentrations studied. As shown in Figure 7, the viability of the cells was determined to lie between $72.5 \pm 1.0 \%$ and $56.9 \pm 1.0 \%$ across the concentration range of 25 to $500 \mu \mathrm{g} / \mathrm{ml}$, indicating that the $\mathrm{LC}_{50}$ of the cells is not reached even at a concentration of $500 \mu \mathrm{g} / \mathrm{ml}$, the highest concentration used in this series of experiments. Clearly the shell inhibits release of free cadmium ions, limiting the cell death.

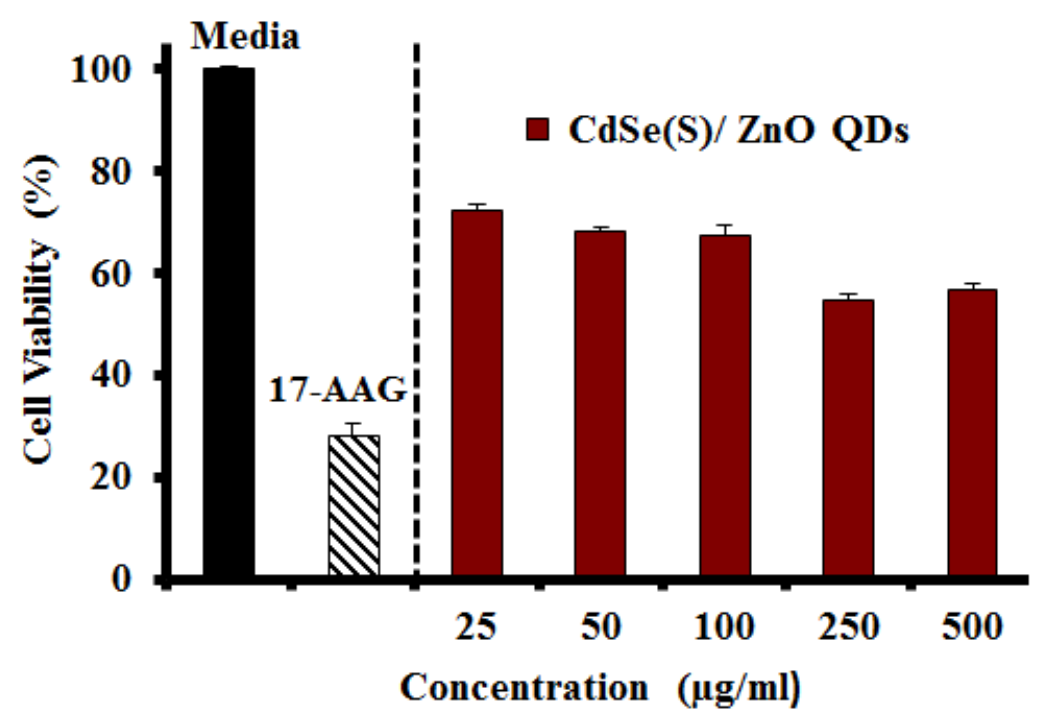

Figure 7. The results of cytotoxicity assays of $\mathrm{CdSe}(\mathrm{S}) / \mathrm{ZnO}$ core/shell QDs toward HCT-116 cell line. Error bars indicate standard error of the mean and the concentration of 17-AAG was $0.06 \mu \mathrm{g} / \mathrm{ml}$

3.2.6 Cytotoxicity assays toward WS1 cells: Human skin fibroblast (WS1) cells were used to determine the cytotoxicity of the as-synthesized QDs toward normal, resilient cells. The results showed that both $\mathrm{CdSe}(\mathrm{S})$ and $\mathrm{CdSe}(\mathrm{S}) / \mathrm{ZnO}$ QDs exhibited low toxicity at all of the concentrations studied (Figure 8), whilst the viability of HCT-116 cells was significantly decreased after incubation with both $\mathrm{CdSe}(\mathrm{S})$ and $\mathrm{CdSe}(\mathrm{S}) / \mathrm{ZnO}$ QDs at all concentrations (Figures $6 \& 7$ ). This indicates that cell resistance is another important factor in cytotoxicity assessments. 


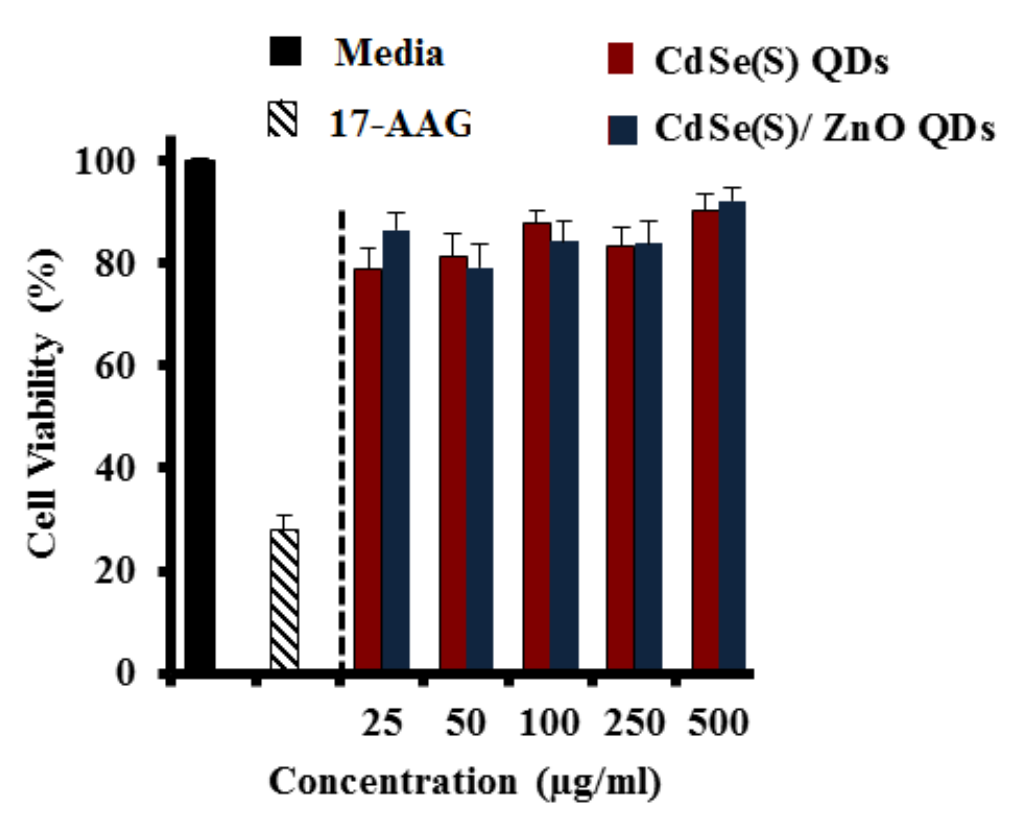

Figure 8. The results of cytotoxicity assays of $\mathrm{CdSe}(\mathrm{S})$ and $\mathrm{CdSe}(\mathrm{S}) / \mathrm{ZnO}$ QDs toward WS1 cell line. Error bars indicate standard error of the mean and the concentration of 17-AAG was $0.06 \mu \mathrm{g} / \mathrm{ml}$

3.3 Confocal microscopy studies: Images of HCT-116 cells after treatment with QDs confirmed the cytotoxicity data. As can be seen in Figures $9 a \& b$, where only the cell nuclei are visible by Hoechst or DAPI staining, many cells remained stable after treatment with $\mathrm{CdSe}(\mathrm{S})$ QDs at $100 \mu \mathrm{g} / \mathrm{ml}$. The images show highly luminescent CdSe(S) QDs present in both the fixed and live cells, with no determinable loss of brightness. Live HCT-116 cells were also incubated with $\mathrm{CdSe}(\mathrm{S}) / \mathrm{ZnO}$ QDs, confocal images of which showed that whilst $\mathrm{CdSe}(\mathrm{S}) / \mathrm{ZnO}$ QDs aggregated in the biological media, many cells remained stable in presence of QDs (Figure 9c). 


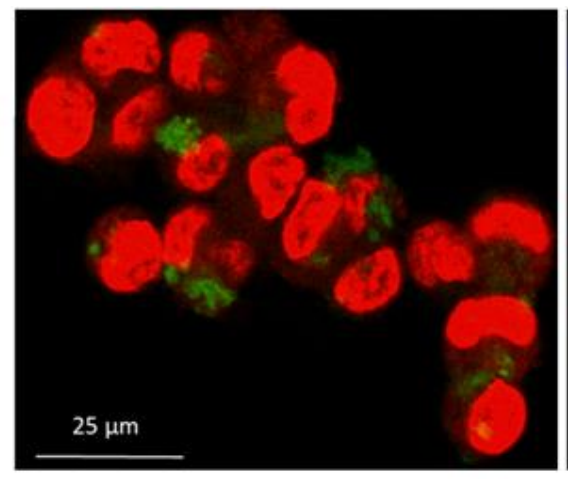

(a)

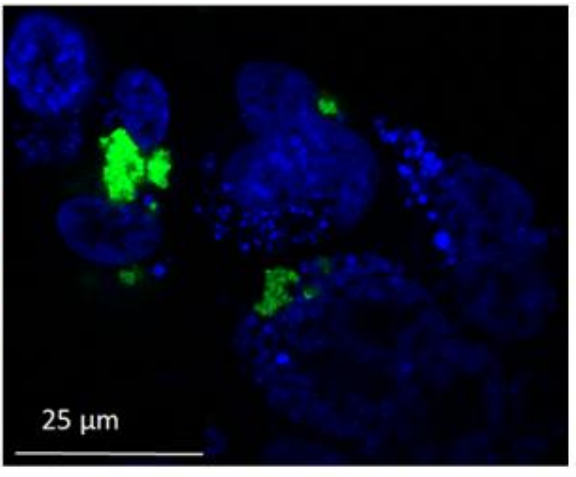

(b)

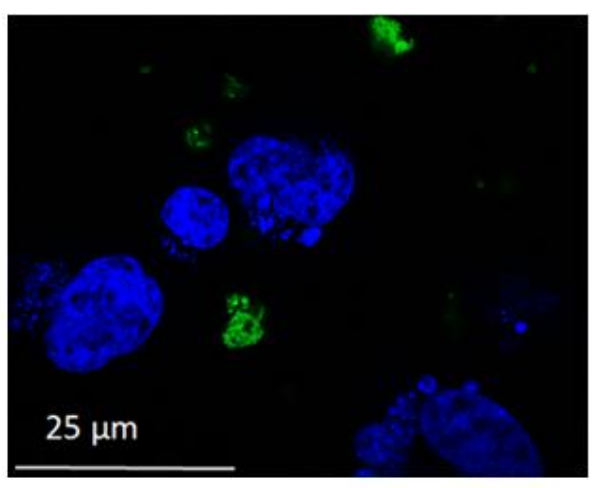

(c)

Figure 9. Confocal image of HCT-116 cells) -QDs: (a) fixed cells: cells (red) and CdSe(S) QDs (green), (b) live cells: cells (blue) and $\mathrm{CdSe}(\mathrm{S})$ QDs (green), (c) live cells (blue) and CdSe(S)/ZnO QDs (green).

The emission profiles of QDs in both the cell media and water were recorded using a confocal microscope in order to determine any changes in photoluminescence spectra of QDs in cell media (Figure 10a). The photoluminescence emission of $\mathrm{CdSe}(\mathrm{S})$ QDs were found with no change in cell media, in contrast to literature reports which have indicated that water soluble MPA-capped CdTe QDs had an altered emission profile in cell growth media [65]. Emission spectra indicated that $\mathrm{CdSe}(\mathrm{S})$ QDs have a maximum emission at $548 \mathrm{~nm}$ in the cell media, with no significant change or shift in photoluminescence relative to that in water. The emission of $\mathrm{CdSe}(\mathrm{S}) / \mathrm{ZnO}$ QDs was found to have a lower intensity and shift to $546 \mathrm{~nm}$ in cell media from $556 \mathrm{~nm}$ in water (Figure $10 \mathrm{~b}$ ). 


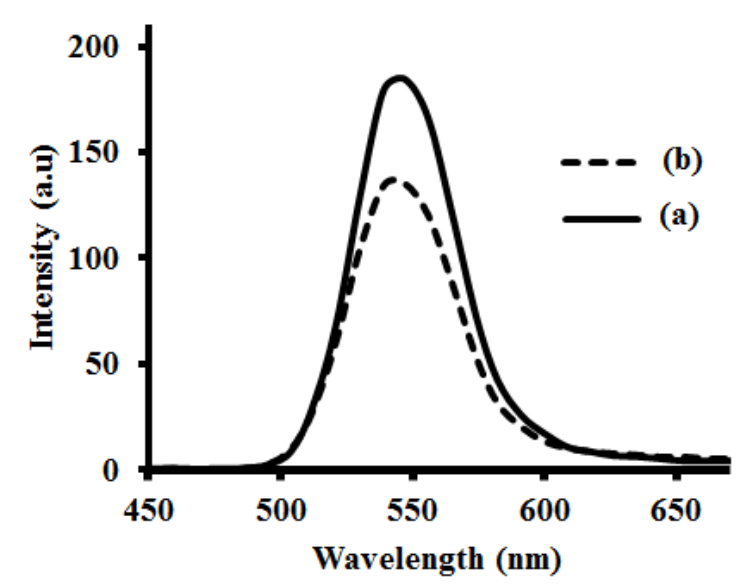

(A)

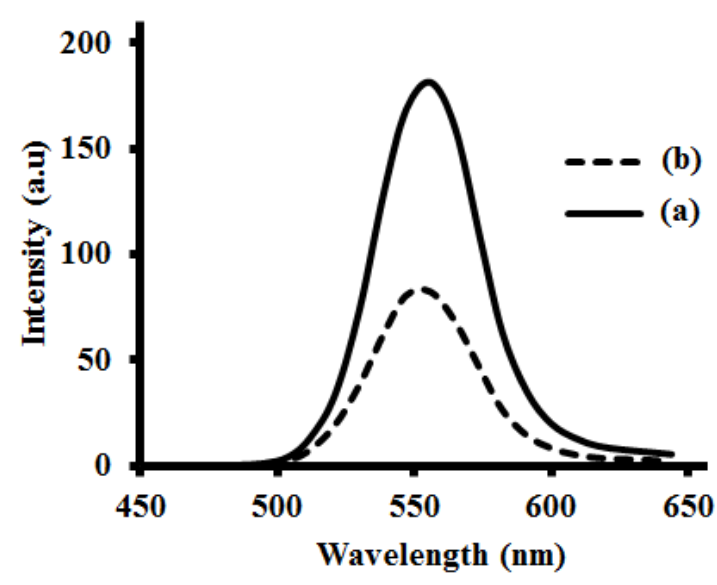

(B)

Figure 10. Photoluminescence spectra of $\mathrm{CdSe}(\mathrm{S}) \mathrm{QDs}(\mathrm{A})$ and $\mathrm{CdSe}(\mathrm{S}) / \mathrm{ZnO}$ QDs (B):

(a) in water and (b) in cell media. The excitation wavelength of the instrument was adjusted at $405 \mathrm{~nm}$ in time of measuring PL.

\section{Conclusions}

We have shown that the cytotoxicity of QDs can be controlled with the aqueous synthesis of stable QDs. It was determined that coating of QDs with a $\mathrm{ZnO}$ shell protects the core against oxidation and the production of toxic free radicals, resulting in decreased cytotoxicity of QDs, even at high concentrations. Images of cells after incubation with QDs at a concentration of $100 \mu \mathrm{g} / \mathrm{ml}$ indicated that the cells remained viable, confirming the cytotoxicity data. The stability of the QD cores in the cell media was found to be related to the overall toxicity of QDs, which is largely governed by the free Cd-ion concentration.

\section{Acknowledgments}

We would like to thank School of Chemistry and the Mark Wainwright Analytical Centre of University of New South Wales for facilities and Ms. Katerina Bendova and Dr. Renee Wan for their assistance about confocal images. 


\section{References}

[1]. B.A. Kairdolf, A.M. Smith, T.H. Stokes, M.D. Wang, A.N. Young, S. Nie, Semiconductor quantum dots for bioimaging and biodiagnostic applications, Annu. Rev. Anal. Chem., 6 (2013) 143-162.

[2]. A.M. Smith, G. Ruan, M.N. Rhyner, S. Nie, Engineering luminescent quantum dots for in vivo molecular and cellular imaging, Ann Biomed Eng., 34 (2006) 3-14.

[3]. I.L. Medintz, H.T. Uyeda, E.R. Goldman, H. Mattoussi, Quantum dot bioconjugates for imaging, labelling and sensing, Nat. Mater., 4 (2005) 435-446.

[4]. X. Yu, L. Chen, K. Li, Y. Li, S. Xiao, X. Luo, J. Liu, L. Zhou, Y. Deng, D. Pang, Q. Wang, Immunofluorescence detection with quantum dot bioconjugates for hepatoma in vivo, J. Biomed. Opt., 12 (2007) 014008/014001-014008/014005.

[5]. I.L. Medintz, A.R. Clapp, H. Mattoussi, E.R. Goldman, B. Fisher, J.M. Mauro, Selfassembled nanoscale biosensors based on quantum dot FRET donors, Nat. Mater., 2 (2003) 630-638.

[6]. X. Michalet, F.F. Pinaud, L.A. Bentolila, J.M. Tsay, S. Doose, J.J. Li, G. Sundaresan, A.M. Wu, S.S. Gambhir, S. Weiss, Quantum Dots for Live Cells, in Vivo Imaging, and Diagnostics, Science, 307 (2005) 538-544.

[7]. E. Petryayeva, W.R. Algar, I.L. Medintz, Quantum dots in bioanalysis: a review of applications across various platforms for fluorescence spectroscopy and imaging, Appl. Spectrosc., 67 (2013) 215-252.

[8]. L. Qi, X. Gao, Emerging application of quantum dots for drug delivery and therapy, Expert Opin. Drug Delivery, 5 (2008) 263-267.

[9]. A. Sadaf, B. Zeshan, Z. Wang, R. Zhang, S. Xu, C. Wang, Y. Cui, Toxicity evaluation of hydrophilic CdTe quantum dots and CdTe@SiO2 nanoparticles in mice, J. Nanosci. Nanotechnol., 12 (2012) 8287-8292.

[10]. A. Nel, T. Xia, L. Maedler, N. Li, Toxic Potential of Materials at the Nanolevel, Science, 311 (2006) 622-627.

[11]. N. Chen, Y. He, Y. Su, X. Li, Q. Huang, H. Wang, X. Zhang, R. Tai, C. Fan, The cytotoxicity of cadmium-based quantum dots, Biomaterials, 33 (2012) 1238-1244.

[12]. V. Labhasetwar, D. Leslie-Plecky, Biomedical Applications of Nanotechnology, Wiley Press, New York, 2007, 229. 
[13]. K. Unfried, C. Albrecht, L.-O. Klotz, A. Von Mikecz, S. Grether-Beck, R.P.F. Schins, Cellular responses to nanoparticles: Target structures and mechanisms, Nanotoxicology, 1 (2007) 52-71.

[14]. H.C. Fischer, W.C.W. Chan, Nanotoxicity: the growing need for in vivo study, Curr. Opin. Biotechnol., 18 (2007) 565-571.

[15]. K.W. Powers, S.C. Brown, V.B. Krishna, S.C. Wasdo, B.M. Moudgil, S.M. Roberts, Research strategies for safety evaluation of nanomaterials. Part VI. Characterization of nanoscale particles for toxicological evaluation, Toxicol. Sci., 90 (2006) 296-303.

[16]. J. Lovric, S.J. Cho, F.M. Winnik, D. Maysinger, Unmodified Cadmium Telluride Quantum Dots Induce Reactive Oxygen Species Formation Leading to Multiple Organelle Damage and Cell Death, Chem. Biol, 12 (2005) 1227-1234.

[17]. N. Singh, B. Manshian, G.J.S. Jenkins, S.M. Griffiths, P.M. Williams, T.G.G. Maffeis, C.J. Wright, S.H. Doak, NanoGenotoxicology: The DNA damaging potential of engineered nanomaterials, Biomaterials, 30 (2009) 3891-3914.

[18]. N. Li, C. Sioutas, A. Cho, D. Schmitz, C. Misra, J. Sempf, M. Wang, T. Oberley, J. Froines, A. Nel, Ultrafine particulate pollutants induce oxidative stress and mitochondrial damage, Environ. Health Perspect., 111 (2003) 455-460.

[19]. R. Mejias, L. Gutierrez, G. Salas, S. Perez-Yague, T.M. Zotes, F.J. Lazaro, M.P. Morales, D.F. Barber, Long term biotransformation and toxicity of dimercaptosuccinic acid-coated magnetic nanoparticles support their use in biomedical applications, J. Controlled Release, 171 (2013) 225-233.

[20]. W.G. Kreyling, M. Semmler-Behnke, W. Moeller, Health implications of nanoparticles, J. Nanopart. Res., 8 (2006) 543-562.

[21]. K.L. Aillon, Y. Xie, N. El-Gendy, C.J. Berkland, M.L. Forrest, Effects of nanomaterial physicochemical properties on in vivo toxicity, Adv. Drug Delivery Rev., 61 (2009) 457466.

[22]. L. Wang, H. Zheng, Y. Long, M. Gao, J. Hao, J. Du, X. Mao, D. Zhou, Rapid determination of the toxicity of quantum dots with luminous bacteria, J. Hazard. Mater., 177 (2010) 1134-1137.

[23]. T.S. Hauck, R.E. Anderson, H.C. Fischer, S. Newbigging, W.C.W. Chan, In vivo Quantum-Dot Toxicity Assessment, Small, 6 (2010) 138-144.

[24]. B. Ballou, B.C. Lagerholm, L.A. Ernst, M.P. Bruchez, A.S. Waggoner, Noninvasive imaging of quantum dots in mice, Bioconjugate Chem., 15 (2004) 79-86. 
[25]. W.-h. Chan, N.-h. Shiao, Cytotoxic effect of CdSe quantum dots on mouse embryonic development, Acta Pharmacol Sin, 29 (2008) 259-266.

[26]. A. Valipoor, G. Amiri, K. Parivar, M. Modaresi, J. Taheri, A. Kazemi, M. Abasi, A. Mirzakhani, A comparative study about toxicity of CdSe quantum dots on reproductive system development of mice and controlling this toxicity by $\mathrm{ZnS}$ coverage, Nanomedicine Journal, 2 (2015) 261-268.

[27]. R. Li, F. Jiang, Q. Xiao, J. Li, X. Liu, Q. Yu, Y. Liu, C. Zeng, Microcalorimetric, spectroscopic and microscopic investigation on the toxic effects of CdTe quantum dots on Halobacterium halobium R1, Nanotechnology, 21 (2010) 475102/475101$475102 / 475110$.

[28]. M. Yan, Y. Zhang, K. Xu, T. Fu, H. Qin, X. Zheng, An in vitro study of vascular endothelial toxicity of CdTe quantum dots, Toxicology, 282 (2011) 94-103.

[29]. V. Brunetti, H. Chibli, R. Fiammengo, A. Galeone, M.A. Malvindi, G. Vecchio, R. Cingolani, J.L. Nadeau, P.P. Pompa, InP/ZnS as a safer alternative to CdSe/ZnS core/shell quantum dots: in vitro and in vivo toxicity assessment, Nanoscale, 5 (2013) 307-317

[30]. A.M. Derfus, W.C.W. Chan, S.N. Bhatia, Probing the Cytotoxicity of Semiconductor Quantum Dots, Nano Lett., 4 (2004) 11-18.

[31]. S. Chang, D. Chen, B. Kang, Y. Dai, UV-enhanced cytotoxicity of CdTe quantum dots in PANC-1 cells depend on their size distribution and surface modification, J. Nanosci. Nanotechnol., 13 (2013) 751-754.

[32]. W.J. Parak, T. Pellegrino, C. Plank, Labelling of cells with quantum dots, Nanotechnology, 16 (2005) R9-R25.

[33]. Q. Wang, T. Fang, P. Liu, X. Min, X. Li, Study of the bioeffects of CdTe quantum dots on Escherichia coli cells, J. Colloid Interface Sci., 363 (2011) 476-480.

[34]. M. Ando, M. Horie, Y. Akazawa-Ogawa, Y. Hagihara, N. Murase, Y. Shigeri, Cytotoxicity of CdSe-based quantum dots incorporated in glass nanoparticles evaluated using human keratinocyte HaCaT cells, Biosci., Biotechnol., Biochem., 80 (2016) 210213.

[35]. L. Lai, J.-C. Jin, Z.-Q. Xu, P. Mei, F.-L. Jiang, Y. Liu, Necrotic cell death induced by the protein-mediated intercellular uptake of CdTe quantum dots, Chemosphere, 135 (2015) 240-249. 
[36]. R. Schneider, C. Wolpert, H. Guilloteau, L. Balan, J. Lambert, C. Merlin, The exposure of bacteria to CdTe-core quantum dots: the importance of surface chemistry on cytotoxicity, Nanotechnology, 20 (2009) 225101/225101-225101/225110.

[37]. X. Li, Z. Yan, J. Xiao, G. Liu, Y. Li, Y. Xiu, Cytotoxicity of CdSe quantum dots and corresponding comparison with FITC in cell imaging efficiency, Int J Clin Exp Med, 10 (2017) 753-759.

[38]. G. Guo, W. Liu, J. Liang, Z. He, H. Xu, X. Yang, Probing the cytotoxicity of CdSe quantum dots with surface modification, Materials Letters, 61 (2007) 1641-1644.

[39]. E. Oh, R. Liu, A. Nel, K.B. Gemill, M. Bilal, Y. Cohen, I.L. Medintz, Meta-analysis of cellular toxicity for cadmium-containing quantum dots, Nat Nano, 11 (2016) 479-486.

[40]. Y. Su, M. Hu, C. Fan, Y. He, Q. Li, W. Li, L.-h. Wang, P. Shen, Q. Huang, The cytotoxicity of CdTe quantum dots and the relative contributions from released cadmium ions and nanoparticle properties, Biomaterials, 31 (2010) 4829-4834.

[41]. X. Li, N. Chen, Y. Su, Y. He, M. Yin, M. Wei, L. Wang, W. Huang, C. Fan, Q. Huang, Autophagy-Sensitized Cytotoxicity of Quantum Dots in PC12 Cells, Adv. Healthcare Mater., 3 (2014) 354-359.

[42]. Y.J. Bao, J.J. Li, Y.T. Wang, L. Yu, L. Lou, W.J. Du, Z.Q. Zhu, H. Peng, J.Z. Zhu, Probing cytotoxicity of CdSe and CdSe/CdS quantum dots, Chin. Chem. Lett., 22 (2011) 843-846.

[43]. Y. Su, Y. He, H. Lu, L. Sai, Q. Li, W. Li, L. Wang, P. Shen, Q. Huang, C. Fan, The cytotoxicity of cadmium based, aqueous phase - Synthesized, quantum dots and its modulation by surface coating, Biomaterials, 30 (2008) 19-25.

[44]. F. Aldeek, C. Mustin, L. Balan, G. Medjahdi, T. Roques-Carmes, P. Arnoux, R. Schneider, Enhanced Photostability from $\mathrm{CdSe}(\mathrm{S}) / \mathrm{ZnO}$ Core/Shell Quantum Dots and their use in Biolabeling, Eur. J. Inorg. Chem., (2011) 794-801.

[45]. M. C. Phelan, In Current Protocols in Cell Biology, John Wiley \& Sons, Inc., 2007, pp. 1.1.1-1.1.18.

[46]. Q. Wang, X. Zhou, T. Fang, P. Liu, X. Li, X. Min, One-step growth of high-quality CdTe quantum dots via hydrothermal method and cytotoxicity evaluation, Powder Technol., 247 (2013) 81-86.

[47]. Y. Li, L. Jing, R. Qiao, M. Gao, Aqueous synthesis of CdTe nanocrystals: progresses and perspectives, Chem. Commun., 47 (2011) 9293-9311. 
[48]. F. Mirnajafizadeh, D. Ramsey, S. McAlpine, F. Wang, P. Reece, J.A. Stride, Hydrothermal synthesis of highly luminescent blue-emitting $\mathrm{ZnSe}(\mathrm{S})$ quantum dots exhibiting low toxicity, Mater. Sci. Eng., C, 64 (2016) 167-172.

[49]. M. Cirillo, T. Aubert, R. Gomes, R. Van Deun, P. Emplit, A. Biermann, H. Lange, C. Thomsen, E. Brainis, Z. Hens, "Flash" Synthesis of CdSe/CdS Core-Shell Quantum Dots, Chemistry of Materials, 26 (2014) 1154-1160.

[50]. C. Kirchner, T. Liedl, S. Kudera, T. Pellegrino, A.M. Javier, H.E. Gaub, S. Stoelzle, N. Fertig, W.J. Parak, Cytotoxicity of Colloidal CdSe and CdSe/ZnS Nanoparticles, Nano Lett., 5 (2005) 331-338.

[51]. F. Yang, P. Yang, Effect of CdS Interlayer on Properties of CdTe Based Quantum Dots, J. Cluster Sci., 24 (2013) 643-656.

[52]. Y. Liu, P. Wang, Y. Wang, Z. Zhu, F. Lao, X. Liu, W. Cong, C. Chen, Y. Gao, Y. Liu, The Influence on Cell Cycle and Cell Division by Various Cadmium-Containing Quantum Dots, Small, 9 (2013) 2440-2451.

[53]. B.A. Rzigalinski, J.S. Strobl, Cadmium-containing nanoparticles: Perspectives on pharmacology and toxicology of quantum dots, Toxicology and Applied Pharmacology, 238 (2009) 280-288.

[54]. F. Mirnajafizadeh, F. Wang, P. Reece, J.A. Stride, Synthesis of type-II CdSe(S)/Fe2O3 core/shell quantum dots: the effect of shell on the properties of core/shell quantum dots, J. Mater. Sci., 51 (2016) 5252-5258.

[55]. The International Centre for Diffraction Data (ICDD), 1978, JCPDs files, No. 00.190191.

[56]. The International Centre for Diffraction Data (ICDD), 1978, JCPDs files, No. 00-0100454.

[57]. F. Mirnajafizadeh, Synthesis and investigation of the properties of water soluble quantum dots for bioapplications., PhD Thesis, University of New South Wales, 2015.

[58]. H. Qian, X. Qiu, L. Li, J. Ren, Microwave-assisted aqueous synthesis: a rapid approach to prepare highly luminescent $\mathrm{ZnSe}(\mathrm{S})$ alloyed quantum dots, J Phys Chem B, 110 (2006) 9034-9040.

[59]. A.L. Rogach, T. Franzl, T.A. Klar, J. Feldmann, N. Gaponik, V. Lesnyak, A. Shavel, A. Eychmueller, Y.P. Rakovich, J.F. Donegan, Aqueous Synthesis of Thiol-Capped CdTe Nanocrystals: State-of-the-Art, J. Phys. Chem. C, 111 (2007) 14628-14637.

[60]. F. J. Moulder, F. W. Stickle, E. P. Sobol, D. K. Bomben, Hand book of X-ray photoelectron spectroscopy. Second Edition, Perkin Elements, 1992, p 81. 
[61]. Z. Solarova, J. Mojzis, P. Solar, Hsp90 inhibitor as a sensitizer of cancer cells to different therapies, Int. J. Oncol., 46 (2015) 907-926.

[62]. L.H. Pearl, C. Prodromou, Structure and in vivo function of Hsp90, Curr. Opin. Struct. Biol., 10 (2000) 46-51.

[63]. T. Horibe, A. Torisawa, M. Kohno, K. Kawakami, Molecular mechanism of cytotoxicity induced by Hsp90-targeted Antp-TPR hybrid peptide in glioblastoma cells, Mol. Cancer, 11 (2012) 59.

[64]. M. Gao, S. Kirstein, H. Möhwald, A.L. Rogach, A. Kornowski, A. Eychmüller, H. Weller, Strongly Photoluminescent CdTe Nanocrystals by Proper Surface Modification, The Journal of Physical Chemistry B, 102 (1998) 8360-8363.

[65]. V. Kulvietis, G. Streckyte, R. Rotomskis, Spectroscopic investigations of CdTe quantum dot stability in different aqueous media, Lith. J. Phys., 51 (2011) 163-171. 


\title{
Supplementary Data
}

\section{Nanoparticles for Bioapplications: Study of the Cytotoxicity of Water Dispersible Quantum Dots}

\author{
Fatemeh Mirnajafizadeh**1 ${ }^{2}$ Deborah Ramsey**1, Shelli McAlpine ${ }^{1}$, Fan Wang ${ }^{2}$,
} Peter Reece ${ }^{2}$ and John Arron Stride ${ }^{1 *}$

1. School of Chemistry, University of New South Wales, Sydney, NSW 2052, Australia

2. School of Physics, University of New South Wales, Sydney, NSW 2052, Australia

3. School of Mathematical and Physical Sciences, University of Technology Sydney, Ultimo, Sydney, NSW 2007, Australia

* Corresponding Author: A/Prof. John Arron Stride

** These authors contributed equally in this work.

\section{S1. Synthesis of Water Dispersible QDs}

S.1.1. Synthesis of $\mathbf{C d S e}(\mathbf{S})$ QDs: $\operatorname{CdSe}(\mathrm{S})$ QDs were prepared according to a modified literature method [1]. Briefly, a Cd-MPA precursor solution was prepared by dissolving 1.48 $\mathrm{g}(6.5 \mathrm{mmol}) \mathrm{CdCl}_{2}$ in $100 \mathrm{ml}$ ultrapure water and adding MPA $(0.7 \mathrm{ml})$ to the solution making the molar ratio of $\mathrm{Cd}$ :MPA $6.5: 8$; the $\mathrm{pH}$ was adjusted to 12.5 using $1 \mathrm{M} \mathrm{NaOH}$, this was labelled Sample 1. Sample 1 was then placed under nitrogen for 10 minutes and NaHSe (1 mmol, $20 \mathrm{ml}$ ), was injected to the solution to form a Cd-Se-MPA complex as a clear yellow liquid; this was labelled as Sample 2. Sample 2 was transferred to a Teflon-lined autoclave and placed in a conventional oven for 1 hour, under hydrothermal treatment at $T=$ $150^{\circ} \mathrm{C}$. Finally, CdSe-MPA capped QDs were formed in an aqueous orange solution and labelled as Sample 3. The as-prepared QDs were orange in colour in contrast to that previously reported [1], with a yellow emission colour under UV light.

S.1.2. Synthesis of $\mathrm{CdSe}(\mathrm{S}) / \mathrm{ZnO}$ QDs: $\mathrm{CdSe}(\mathrm{S})$ QDs were prepared, as described in section S.1.1 and coated with $\mathrm{ZnO}$ according to previous literature report [1], based upon the controlled hydrolysis of zinc salts at basic pH. First, an aqueous suspension of as-prepared $\mathrm{CdSe}(\mathrm{S})$ QDs (Sample 3, described in S.1.1), was diluted using ultrapure water. The 
concentration of $\mathrm{CdSe}(\mathrm{S})$ QDs was $1.7 \mathrm{mg}$ in $5 \mathrm{ml}$ and the $\mathrm{pH}$ was adjusted to $13 \mathrm{using} 1 \mathrm{M}$ $\mathrm{NaOH}$. This solution was refluxed for 2 hours before injecting an aqueous solution of $\mathrm{Zn}(\mathrm{OAC})_{2} .2 \mathrm{H}_{2} \mathrm{O}(18 \mathrm{ml}, 0.01 \mathrm{M})$ at $T=100^{\circ} \mathrm{C}$. Reflux was continued for another hour and $\mathrm{CdSe}(\mathrm{S}) / \mathrm{ZnO}$ core/shell QDs were obtained as orange nanoparticles.

\section{S2. Cell Culture of HCT-116 and WS1 Cells}

Cell cultures of human colorectal carcinoma cells (HCT-116) and human skin fibroblast cell line (WS-1) were obtained according to the standard protocol [2]. As cells are usually received frozen in the culture medium with 5-10\% dimethyl sulfoxide (DMSO) in the vapour of liquid nitrogen at $77 \mathrm{~K}$, they were first defrosted to $37^{\circ} \mathrm{C}$ and the culture medium discarded by using a centrifuge at $1500 \mathrm{rpm}$ for 5 minutes. Then, the HCT-116 and WS-1 cells were separately resuspended in Dulbecco's Modified Eagle Medium (DMEM) supplemented with $10 \%$ fetal bovine serum (FBS), 1\% penicillin/streptomycin, (1\%) nonessential amino acid and L-glutamine $(2 \mathrm{mM})$ as growth medium and transferred in two $75 \mathrm{~cm}^{2}$ flasks. Finally, the cells were grown in a humidified incubator at $37^{\circ} \mathrm{C}$ with $5 \% \mathrm{CO}_{2}$ and as cells reached confluence; they were immediately used for cytotoxicity tests in separate experiments.

\section{S3. Preparation of HCT-116 cells-CdSe(S) QDs Samples}

S.3.1. Fixed HCT 116 cells-CdSe(S) QDs sample: cells were cultured (as described in S2) and were seeded in $35 \mathrm{~mm}$ fluorodish cell culture dishes at a density of 20000 cell/dish for 24 hours. The cells were then treated with an aqueous solution of $\mathrm{CdSe}(\mathrm{S}) \mathrm{QDs}(250 \mu \mathrm{g} / \mathrm{ml})$ and incubated at $37^{\circ} \mathrm{C}$ with $5 \% \mathrm{CO}_{2}$ for 24 hours. After incubation, the cells were fixed with $4 \%$ paraformaldehyde in PBS for 1 hour, before finally being washed with PBS and stained with $5 \mu \mathrm{g} / \mathrm{ml}$ bisbenzimide (Hoechst 33342) for 20 minutes in room temperature.

S.3.2. Live HCT 116 cells-QDs samples: cells were cultured according to the standard protocol [2] similar to the fixed cells and were seeded in a 24-well glass bottom plate at a density of 20000 cells/dish for 24 hours. Then, cells were treated with an aqueous solution of 
$\mathrm{CdSe}(\mathrm{S})$ QDs $(100 \mu \mathrm{g} / \mathrm{ml})$ and incubated at $37^{\circ} \mathrm{C}$ with $5 \% \mathrm{CO}_{2}$ for 24 hours. As-prepared samples were used for confocal microscopy studies.

S4. The comparison of PXRD of $\mathrm{CdSe}(\mathrm{S})$ QDs with cubic CdSe and CdS standard peaks

The diffraction peaks of $\mathrm{CdSe}(\mathrm{S})$ QDs were observed between standard cubic CdSe [3] and CdS [4], as shown in Table $S_{1}$.

Table $S_{1}$. The comparison of diffraction peaks of as-synthesized CdSe(S) QDs with cubic CdSe and CdS standard peaks

\begin{tabular}{|c|c|c|c|}
\hline h k l & $\begin{array}{c}\text { CdSe cubic } \\
\text { (Standard pattern) }\end{array}$ & $\begin{array}{c}\text { As -synthesized } \\
\text { CdSe(S) QDs }\end{array}$ & $\begin{array}{c}\text { CdS cubic } \\
\text { (Standard pattern) }\end{array}$ \\
\hline 111 & 25.35 & 26.29 & 26.50 \\
\hline 220 & 42.00 & 43.66 & 53.96 \\
\hline 311 & 49.69 & 51.67 & 52.13 \\
\hline
\end{tabular}

\section{References}

[1]. F. Aldeek, C. Mustin, L. Balan, G. Medjahdi, T. Roques-Carmes, P. Arnoux, R. Schneider, Enhanced Photostability from $\mathrm{CdSe}(\mathrm{S}) / \mathrm{ZnO}$ Core/Shell Quantum Dots and their use in Biolabeling, Eur. J. Inorg. Chem., (2011) 794-801.

[2]. M. C. Phelan, In Current Protocols in Cell Biology, John Wiley \& Sons, Inc., 2007, pp. 1.1.1-1.1.18.

[3]. The International Centre for Diffraction Data (ICDD), 1978, JCPDs files, No. 00.190191.

[4]. The International Centre for Diffraction Data (ICDD), 1978, JCPDs files, No. 00-0100454. 